\title{
SALICYLIC ACID TREATMENT INCREASES SALT TOLERANCE OF WHEAT PLANTS BY ENHANCING ANTIOXIDANT DEFENSE SYSTEMS
}

\author{
Abdel Kareem S.H. Mohamed
}

Botany and Microbiology Department, Faculty of Science, Al-Azhar University, Assiut 71524 Egypt.

\begin{abstract}
The present study was conducted to assess influence of salinity and varying concentrations of salicylic acid (0.5 mM and $1 \mathrm{mMSA}$ ) on growth, antioxidant enzyme activities and biochemical activities of wheat plants. Wheat (cv. Sods 12) was grown in a normal clay soil for 30 days. The treatments comprised of control, $50 \mathrm{mM} \mathrm{NaCl}, 100 \mathrm{mM} \mathrm{NaCl}$, and $150 \mathrm{mM} \mathrm{NaCl}$. Except control, the concentrations of $\mathrm{NaCl}$ at all levels were applied through irrigation. After harvest, the plant samples were analyzed for photosynthetic pigments, proline content, electrical conductivity, and cell membrane stability. The results show significant decline in vegetative parameters (e.g., dry mass) at higher application rates of salinity and SA (1 mMSA NaCl) as compared to control treatment. The phenolic compounds and ascorbic acid concentrations were reduced after application of $0.5 \mathrm{mM} \mathrm{SA}$ and combined application of $\mathrm{NaCl}$ and $\mathrm{SA}$, while the concentration of Milondialdehyde (MDA) was gradually increased by increasing SA application and were maximum at the highest application level of combined NaCl and $1 \mathrm{mM} \mathrm{SA}$. The level of antioxidant defense systems (catalase and ascorbate peroxidase) increased in response to salicylic acid treatment. Enhanced antioxidant activities helped to decrease oxidative damage from salt and develop tolerance against salt stress in salicylic acid-treated wheat plants. The data provided evidence that salicylic acid treatment reduced the adverse effects of salt stress on wheat plants, and might play a key role in providing stress tolerance by stimulation of the antioxidant system as a stress protection mechanism.
\end{abstract}

Keywords: Wheat; Salicylic acid; Antioxidant enzymes; MDA; Proline; Salinity.

\section{INTRODUCTION:}

Wheat, an important cereal crop in many parts of the world, is considered to be a moderately salt-resistant glycophyte species which reacts with the severe reduction of plant growth and yield under high salt stress, [1]. About 100 million ha or $5 \%$ of the arable land is adversely affected by high salt concentrations that reduce crop growth and yield [2]. Plants growing in saline environments exhibit various strategies at both the whole plant and cell level that allow them to overcome salinity stress. The problems posed to higher plants by a saline environment results from osmotic stress as a result of the difficulty of absorbing water from soil of unusually high osmotic pressure, and ionic stress resulting from concentrations of potentially toxic salt ions higher than the limit to which most plants are adapted for optimum growth. Both of these components of salt stress affect a growing plant by causing changes in membrane chemistry, cell and plant water status, enzyme activities, protein synthesis and gene expression [3-4].

Plants have evolved various strategies to survive under the saline conditions. Salt-resistant plants restrict the accumulation of toxic ions in sensitive tissues by excluding them and/or by sequestering them in old tissues and in vacuoles. However, inhibition of leaf growth during the first phase of salt stress is mainly caused by osmotic problems rather than ion toxicity [5]. Since $\mathrm{Na}+$ translocation to the shoot occurs via the xylem driven by transpiration, the main site for $\mathrm{Na}+$ toxicity in most plants is the leaf blade. As such, all mechanisms which lead to $\mathrm{Na}+$ exclusion from the shoot contribute to salt resistance [6].

Exogenous application of salicylic acid enhanced the photosynthetic rate and also maintained the stability of membranes, thereby improved the growth of salinity stressed barley plants [7]. SA induced an increase in photosynthetic pigments [8]. Thus, salicylic acids activate the synthesis of carotenoids and also enhanced the rate of de-epoxidation with a concomitant decrease in the chlorophyll pigments in wheat plants under salt stress, [9].

Reactive oxygen species (ROS) may cause a damage to photosynthetic pigments [10], lipid peroxidation and protein loss [11], enzyme inhibition and damage to nucleic acid structures [1214]. To overcome the reactive oxygen species, 
a highly enzymatic antioxidant defense system including superoxide dismutase (SOD), catalase, peroxidase, ascorbate peroxidase (APX), and non-enzymatic compounds such as ascorbic acid were studied, [15].

Salicylic acid was found to enhance the activities of antioxidant enzymes, catalase (CAT) and ascorbate peroxidase (APX), when sprayed exogenously to salinity stressed plants of Brassica juncea [16]. Accordingly, the exogenous SA application enhanced the antioxidant defense systems (APX and SOD enzymes) with a concomitant decline in the activity of CAT enzyme in maize plants.

A plenty of literature is available about effects of $\mathrm{NaCl}$ and $\mathrm{SA}$ either combined or alone on various plant species. However, less research has been done on the effect of $\mathrm{NaCl}$ and $\mathrm{SA}$ on growth, and biochemical activities in salt sensitive genotypes of wheat. Hence, the objectives of present study were to examine the effect of different concentrations of $\mathrm{NaCl}$ on cell membrane stability, photosynthetic pigment and proline and lipid peroxidase contents, antioxidant enzyme activities of wheat plants, and to examine the utility of salicylic acid as a promising plant development regulatory substance to increase the salt tolerance of wheat plants.

Materials and methods

Growth experiment

A pot experiment was conducted by using wheat (Triticum aestivum L. cv. Sods 12) as a test plant. The treatments comprised of various concentrations of salicylic acid (SA) and salinity $(\mathrm{NaCl})$. Six treatments in total, i.e. control, $50 \mathrm{mM} \mathrm{NaCl}, 100 \mathrm{mM} \mathrm{NaCl}, 150 \mathrm{mM} \mathrm{NaCl}$, $0.5 \mathrm{mM} \mathrm{SA}$, and $1 \mathrm{mM} \mathrm{SA}$ were used. Grain seeds of salt-sensitive wheat cultivar (cv. Sods 12) were grown in normal clay soil containing 2 $\mathrm{Kg}$ in plastic pots ( $20 \mathrm{~cm}$ in diameter) in greenhouse under natural conditions. All pots were irrigated with tap water until the appearance of fourth true leaves. Phytohormone (SA) solution was prepared by dissolving the required quantity of SA in $5 \mathrm{ml}$ of ethanol, and then the volume was completed $100 \mathrm{ml}$ by distilled H2O. The exogenous application of phytohormone (SA) was sprayed with $20 \mathrm{ml}$ per pot. Control plant and salinized plants were sprayed with distilled $\mathrm{H} 2 \mathrm{O}$. Plants were harvested after 30 days of growth. After harvesting, the shoots and roots were separated, weighed and oven-dried at $105^{\circ} \mathrm{C}$ for 24 hours for dry weight measurements.

\section{Analyses:}

The photosynthetic pigments (chlorophyll a, chlorophyll $\mathrm{b}$ and carotenoids) in leaves were estimated using spectrophotometer following the methods of Lichtenthaler [17]. Chlorophylls and carotenoids concentrations were calculated as $\mathrm{mg} \mathrm{g}-1 \mathrm{FW}$ at 663,644 and $452 \mathrm{~nm}$.

Electrical conductivity of wheat was assessed in order to study the degree of membrane injury caused by salinity and SA. The cell membrane stability was determined as given by Premachandra et al. [18]. with minor modifications.

Free proline content was determined according to Bates et al. [19]. Proline concentration was determined using calibration curve of proline and expressed as $\mathrm{mg} / \mathrm{g}$ DW. The lipid peroxidation (MDA) was determined by measuring malondialdehyde (MDA) formation using the thiobarbituric acid reaction as described by Madhava Rao \& Sresty, [20] with some modifications. The concentration of MDA was calculated by using an extinction coefficient (155 mM-1 cm-1) and the results expressed as SM MDA/g FW.

The concentration of free and total phenolics were determined according to Kofalvi and Nassuth, [21]. Briefly, fresh leaves (0.5 gm) were extracted in $50 \%$ methanol $(1: 1 \mathrm{v} / \mathrm{v})$ for $90 \mathrm{~min}$ at $80^{\circ} \mathrm{C}$. The extract was centrifuged at 14000 rpm for $15 \mathrm{~min}$. Free and total phenolics were determined in the supernatant using the FolinCiocalteu's phenol reagent.

The concentration of ascorbic acid in the leaves was determined according to methods of Jagota and Dani [22].The measurements were made taking the absorbance readings of the blue color developed at $760 \mathrm{~nm}$ using spectrophotometer.

Catalase (CAT) activity (EC 1.11.1.6) was determined Spectrophotometrically by measuring the rate of $\mathrm{H} 2 \mathrm{O} 2$ conversion to $\mathrm{O} 2$. The Bioassay medium contained $2.9 \mathrm{ml}$ of bioassay 
media (K-phosphate buffer at $\mathrm{pH}$ 7.5) containing $3 \mathrm{mM} \mathrm{H} 2 \mathrm{O} 2,0.1 \mathrm{ml}$ of sample tissue extract. The decrease in absorbance at $240 \mathrm{~nm}$ was monitored and the resulted of catatase activity as ( $\Delta$ abs 240 mg-1 dry weight).

Ascorbate Peroxidase (APX) activity (EC1.11.1.1) was determined Spectrophotometrically according to the method of Nakano, and Asada, [23] and Urbanek et al., [24] with same modification. The bioassay reaction contained 50 $\mathrm{mM}$ phosphate buffer ( $\mathrm{pH} 6.0), 0.1 \mu \mathrm{M}$ EDTA, $0.5 \mathrm{mM}$ ascorbate, $1.0 \mathrm{mM} \mathrm{H} 2 \mathrm{O} 2$ and $0.1 \mathrm{mM}$ of sample enzyme extract. The reaction was measured at $290 \mathrm{~nm}$ for $1 \mathrm{~min}$ and the results were expressed in $\mu \mathrm{mol} \mathrm{H} 2 \mathrm{O} 2 \mathrm{~g} \mathrm{FW}$.

\section{Statistical analysis}

Data are means of at least three biological replications. Variation among the biological replications was characterized by standard errors. One-way ANOVA was conducted to analyze the data for variance using SPSS 13.0 computer software. Multiple comparisons separating means in homogenous subgroups were done using the post-hoc Tukey test.

\section{RESULTS AND DISCUSSION:}

Effect of salinity and salicylic acid application on shoot dry mass production:

The results show significant decrease in shoot dry masses of wheat plants as compared to the control. Treatment with salicylic acid and salinity at lower application rates $(0.5 \mathrm{mM} \mathrm{SA}$ $+\mathrm{NaCl}$ ) showed slightly growth reduction of wheat plants. However at higher application rates of both $1 \mathrm{mM} \mathrm{SA}$ and $\mathrm{NaCl}$, no significant effects were observed (Figure 1). High concentration of salt reduces the shoot growth may be due to the increased osmotic pressure or sodium ions within the cytoplasm of leaf cells. Sodium ion could be a toxicity factor resulting in reduced shoot dry weights [25-27].

In our study, a significant growth reduction of the wheat genotype (cv. sods 12) was observed by higher concentration of salicylic acid ( $1 \mathrm{mM}$ SA) and salinity $(150 \mathrm{mM} \mathrm{NaCl})$. Growth was severely reduced under salinity and high level of SA as compared to lower SA concentration (0.5 mM SA). In different studies, salinity treat-

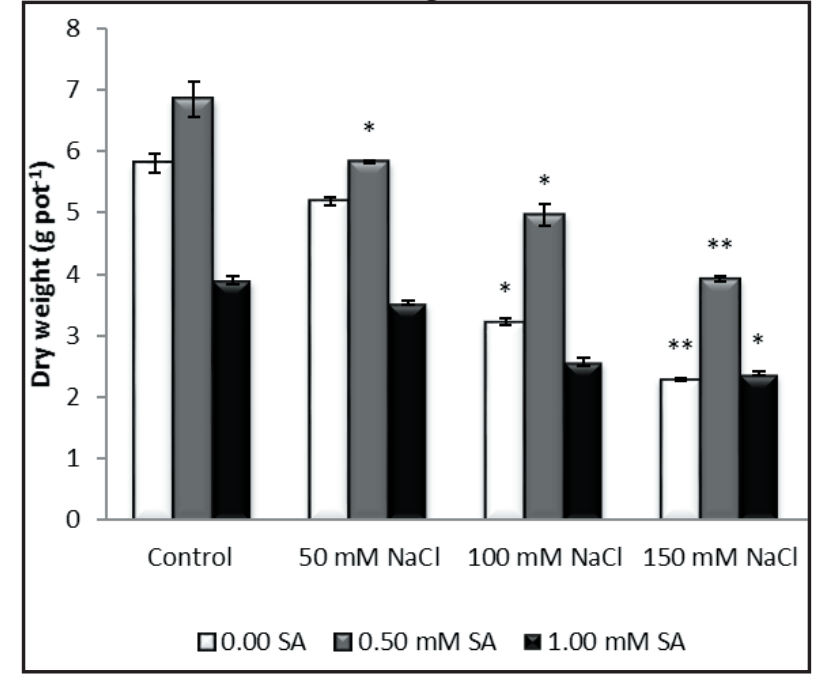

Fig (1): Shoot dry weight of Triticum aestivum grown under different salinity levels and Salicylic acid application (0.00 SA, $0.5 \mathrm{mM}$ SA and $1 \mathrm{mM} \mathrm{SA})$ for 30 days. The results represent means $\pm \mathrm{SE}$ of at least three independent values. Significant differences $(\mathrm{P} \leq \mathbf{5 \%})$ between values are indicated by stars $(*, * *)$.

ments showed significant reduction in maize, sugar beet, and sunflower at the early vegetative growth stage [28]. Mohamed and Shaddad, [29] reported negatively effect of salinity on growth and yield of wheat plants under high salinity stress. It has been reported in many studies that higher concentrations of SA causes decrease photosynthesis and damage to the cell membrane of plant cell [30].

Effect of different salinity levels and exogenously SA application on membrane stability and photosynthetic pigments:

The sole applications of $\mathrm{NaCl}$ and $\mathrm{SA}$ at low levels did not significantly influence the membrane permeability (Fig. 2), while the combined applications of $\mathrm{SA}$ and $\mathrm{NaCl}$ significantly increased the membrane permeability with increasing application rates.

Membrane damage can be evaluated indirectly by measuring solute leakage (electrolyte leakage) from cells [31].There are different parameters which indicate the salt tolerance in plants, one of them is membrane stability index. It was higher in salt tolerant as compared to salt sensitive wheat genotypes [32], but membrane permeability was significantly higher in some plant species under salinity stress along SA ap- 


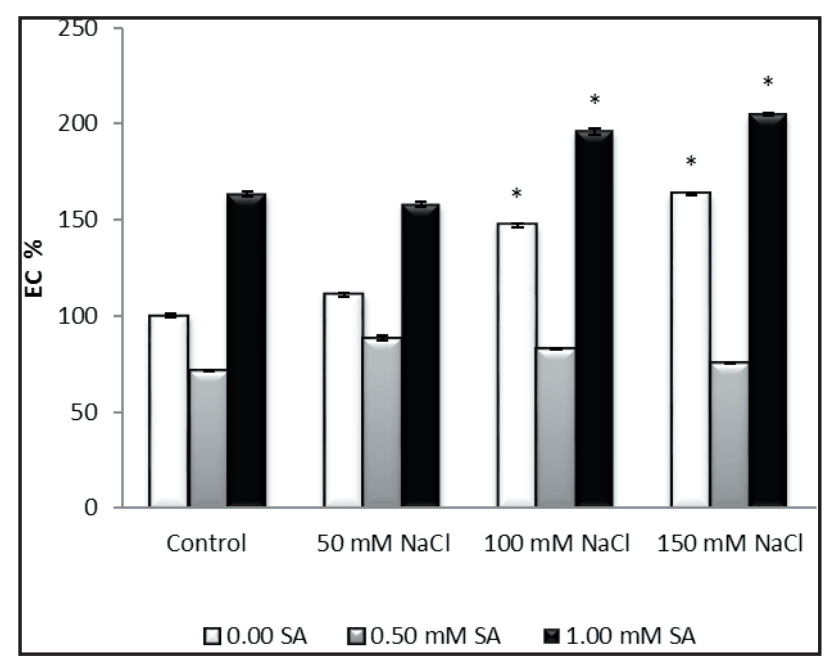

Fig (2): Electric conductivity (EC \%) of Triticum aestivumgrown under different salinity levels and Salicylic acid application (0.00 SA, 0.5 mM SA and $1 \mathrm{mM} \mathrm{SA}$ ) for 30 days. The results represent means $\pm \mathrm{SE}$ of at least three independent values. Significant differences $(P \leq \mathbf{5 \%})$ between values are indicated by stars $(*, * *)$.

plication as is in wheat in this study (Figure 2). Application of salicylic acid corrected the stressmediated damage to the plasma membrane, as was evident from the significant increase in membrane stability and the significant decrease in membrane leakage of treated wheat plants compared with those of the reference controls.

Data presented in Table 1 show that application of $0.5 \mathrm{mM}$ SA significantly increased the total pigments and carotenoid contents as compared to that of control, while SA supply at higher levels did not influence them (Tab. 1). Salt stress either alone or in combination with SA did not affect the total pigments and carotenoids. However combined application of $\mathrm{NaCl}$ and $1 \mathrm{mM}$ SA significantly reduced the total pigments and carotenoid contents. Sole applications of salinity and SA at all levels did not affect the contents of $\mathrm{Chl}$ a and $\mathrm{Chl}$ b. Combined application of $\mathrm{NaCl}$ and $1 \mathrm{mM}$, as compared to control, significantly reduced the Chl a contents (Tab. 1).

These results are consistent with those of Jaleel et al. [33], who found that, at low salinity regimes, a slight decrease was noted in chl a, chl $\mathrm{b}$ and total chlorophyll contents, but under high-salinity conditions a significant reduction in the content of these pigments was observed. In the present study application of salicylic acid alleviated the damage effects of salt stress on photosynthetic pigment contents by increasing the MDA contents (Fig. 3B). In agreement with these results, Palma et al., [34] stated that spray application of salicylic acid enhanced the photosyonthetic apparatus and enzyme activity in beans. It has been suggested that the contents of the photosynthetic pigments were increased in wheat as salicylic acid concentration increased [35].

\section{Proline and MDA contents:}

The application $0.5 \mathrm{mM} \mathrm{SA}$ did not affect the leaf proline concentrations as compared to control treatment (Fig. 3A). However $1 \mathrm{mM} \mathrm{SA} \mathrm{sig-}$ nificantly increased the concentration of proline.

Table (1): photosynthetic pigments (mg g-1 FW) of wheat plant grown under different salinity levels and Salicylic acid application (0.00 SA, $0.5 \mathrm{mM}$ SA and $1 \mathrm{mM} \mathrm{SA})$ for 30 days. The results represent means $\pm \mathrm{SE}$ of at least three independent values.

\begin{tabular}{c|l|c|c|c}
\hline \multicolumn{2}{c}{ Treatments } & \multicolumn{1}{c}{ Chl. $a$} & \multicolumn{1}{c}{ Chl. $b$} & Cartenoids \\
\hline \multirow{3}{*}{$\mathrm{NaCl}$} & Control & $0.022 \pm 1.75$ & $0.005 \pm 0.70$ & $0.012 \pm 0.98$ \\
\cline { 2 - 5 } & $\mathrm{mM} \mathrm{50}$ & $0.015 \pm 1.74$ & $0.026 \pm 0.70$ & $0.015 \pm 0.89$ \\
\cline { 2 - 5 } & $\mathrm{mM} \mathrm{100}$ & $0.022 \pm 1.65$ & $0.011 \pm 0.56$ & $0.020 \pm 0.84$ \\
\cline { 2 - 5 } & $\mathrm{mM} \mathrm{150}$ & $0.027 \pm 1.54$ & $0.023 \pm 0.51$ & $0.028 \pm 0.81$ \\
\hline \multirow{3}{*}{ mM SA 0.5 } & Control & $0.023 \pm 1.93$ & $0.015 \pm 0.81$ & $0.010 \pm 1.20$ \\
\cline { 2 - 5 } & $\mathrm{mM} \mathrm{NaCl} \mathrm{50}$ & $0.040 \pm 2.10$ & $0.027 \pm 0.73$ & $0.020 \pm 1.12$ \\
\cline { 2 - 5 } & $\mathrm{mM} \mathrm{NaCl} \mathrm{100}$ & $0.051 \pm 1.88$ & $0.020 \pm 0.67$ & $0.017 \pm 1.12$ \\
\cline { 2 - 5 } & $\mathrm{mM} \mathrm{NaCl} \mathrm{150}$ & $0.021 \pm 1.82$ & $0.016 \pm 0.61$ & $0.054 \pm 1.24$ \\
\hline
\end{tabular}


On the other hand, salt stress either alone or in combination with high level of SA increased the proline concentrations by more than 10.3 folds as compared to the non-saline control, (Fig. 3A). The combined effect of salinity and salicylic acid on proline concentration was only prominent at $1 \mathrm{mM} \mathrm{SA}+\mathrm{NaCl}$.

Proline content was significantly increased by salinity stress. Recently, Palma et al., [34] reported that proline accumulation in response to salinity stress, protected the cell by balancing the osmotic strength of the cytosol with that of the vacuole and external environment. Proline accumulation could be a protective response, not only because of the osmoprotectant role of proline that prevents water-deficit stress under high salinity, but also as a result of the radical scavenger and protein stabilization properties of proline [30 and 36].
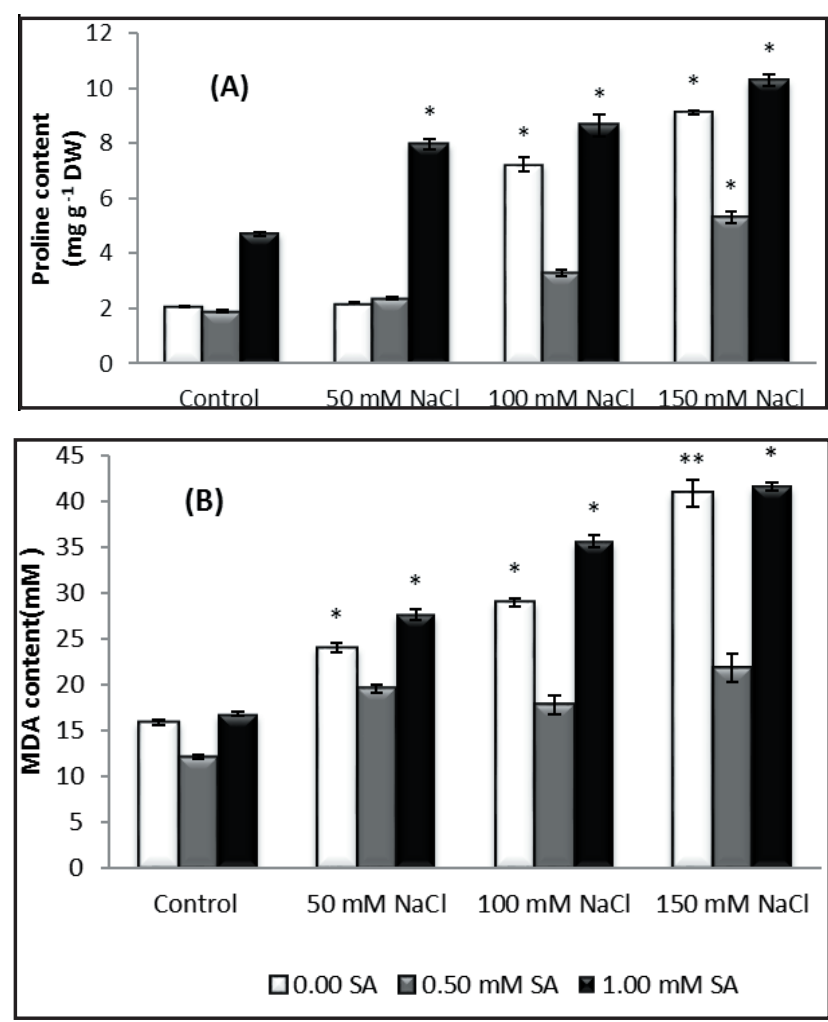

Fig (3): Proline content (A) and MDA content (B) of Triticum aestivum grown under different salinity levels and Salicylic acid application (0.00 SA, $0.5 \mathrm{mM}$ SA and $1 \mathrm{mM} \mathrm{SA}$ ) for 30 days. The results represent means $\pm \mathrm{SE}$ of at least three independent values. Significant differences $(P$ $\leq 5 \%$ ) between values are indicated by stars $(*, * *)$.
Milondialdehyde (MDA) is a decomposition product of lipids and is often utilized as biomarker for lipid peroxidation. Our results show that the MDA concentrations (lipid peroxidase) were gradually increased by SA levels (Fig. 3B); however the significant increase (as compared to control) was only observed at $1 \mathrm{mM} \mathrm{SA}$. Salt stress either enhanced the leaf MDA concentration (Fig. 3B). In comparison to salt stress alone, MDA concentration increased only under application of $1 \mathrm{mM} \mathrm{SA}+150 \mathrm{mM} \mathrm{NaCl}$.

Salinity stress significantly increased concentration of MDA (lipid peroxidation). During abiotic stresses especially salinity causes membrane damage through membrane lipid peroxidation [37]. Our results have a positive correlation between membrane permeability and MDA. Mittler [38] measured $\mathrm{H} 2 \mathrm{O} 2$ and MDA concentrations in leaves that are oxidative stress indicator. $\mathrm{H} 2 \mathrm{O} 2$ caused membrane damage that fasten the Haber-Weiss reaction, by production of hydroxyl radical (OH.-) and lipid peroxidation.

These parameters were significantly increased under high SA concentration in this study (Fig 3B); however there are contradictory results in different studies. Dionisiases and Tobita [39] proposed that there is no relationship between lipid peroxidation and $\mathrm{H} 2 \mathrm{O} 2$ concentration under SA in rice but in other study both $\mathrm{H} 2 \mathrm{O} 2$ and MDA concentrations were increased in mulberry [40] under high SA level. Interestingly, MDA content in T. aestivum plants was significantly decreased in response to salicylic acid treatment, which reinforced the suggestion that salicylic acid treatment can ameliorate the stressful condition by increasing the stability of membranes in T. aestivum.

\section{Antioxidant enzyme activity:}

The results presented in Figure (4) show the effect of different concentrations of $\mathrm{NaCl}$ in control plants or in plants pretreated with salicylic acid on the activities of the antioxidant enzymes CAT and APX in T. asetivum plants at the vegetative stage. The activities of CAT and APX showed progressively increased with increasing $\mathrm{NaCl}$ concentration, compared with those of the non-salt stressed plants, (Fig. 4). On the other hand, salt stress $(100 \mathrm{mM}$ and $150 \mathrm{mM} \mathrm{NaCl})$ 
either alone or in combination with SA levels significantly increased both antioxidant enzyme activites in wheat leaves. The maximum increase in CAT and APX activity was observed where plants were supplied with $150 \mathrm{mM} \mathrm{NaCl}+1 \mathrm{mM}$ SA (Figure 4).

High SA concentration and $\mathrm{NaCl}$ both influence antioxidant activities that scavenge reactive oxidative species (ROS) and metabolites. Under ionic stress, high SA level increases production of ROS. Alscher et al., [41] reported that scavenging ROS through the increased activity of antioxidant enzymes improved salt tolerance as is in wheat in this study (Fig. 4). These results are in agreement with those of Hassanein et al., [42] who observed that salt stress increased the activities of antioxidant enzymes in leaves of maize plants.
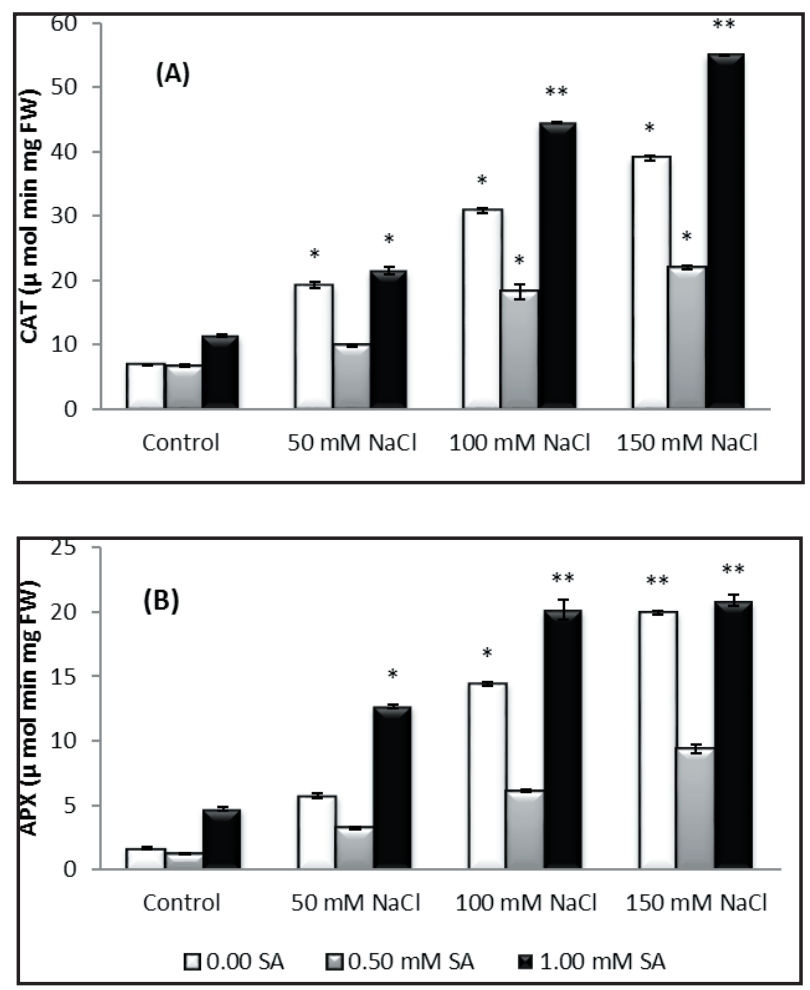

Fig (4): Catalase (A) and ascorbate peroxidase enzymes (B) of Triticum aestivum grown under different salinity levels and salicylic acid application (0.00 SA, $0.5 \mathrm{mM} \mathrm{SA}$ and $1 \mathrm{mM} \mathrm{SA})$ for 30 days. The results represent means $\pm \mathrm{SE}$ of at least three independent values. Significant differences $(P \leq 5 \%)$ between values are indicated by $\operatorname{stars}(*, * *)$.
The significant increase of antioxidants enzymes (Fig. 1) at saline conditions might be due to improved wheat grain yield under salinity leading to improvement plant water relations and osmotic adjustment processes, [42]. [44 - 45] reported increased activity of the antioxidant enzymes is considered to be a salt-tolerance mechanism in most plant species.

Previous studies showed that salt-tolerant cultivars generally have enhanced or higher constitutive antioxidant enzyme activity under salt stress compared with those of salt-sensitive cultivars. Such a trend has been demonstrated in numerous plant species, such as Azolla [46], Crithmum maritimum [47], Medicago truncatula [48] and broad bean and wheat [29]. However, the present results showed that salt stress caused a decrease in CAT activity, which might lead to accumulation of $\mathrm{H} 2 \mathrm{O} 2$ to a toxic level. In this regard, Feierabend et al., [49] showed that under stress conditions inactivation of catalase is linked to $\mathrm{H} 2 \mathrm{O} 2$ accumulation. Salt stress preferentially enhances $\mathrm{H} 2 \mathrm{O} 2$ content and the activities of APX but decreases CAT activity [50]. This can be regarded as dismutation of superoxide to $\mathrm{H} 2 \mathrm{O} 2$.

Application of salicylic acid ameliorated the effect of salinity, reduced the activity of APX and increased the activity of CAT in T. aestivum plants. This increase in CAT activity in response to salt stress in the present study was consistent with the results reported by Gengmao et al., [51]. It has been suggested that, the treated plants with SA concentration possess a better scavenging ability.

\section{Ascorbic acid:}

The application $0.5 \mathrm{mM} \mathrm{SA}$ did not affect the leaf ascorbic acid concentrations as compared to control treatment (Fig. 5). However $1 \mathrm{mM}$ SA significantly decreased the concentration of ascorbic acid. On the other hand, salt stress either alone or in combination with SA decreased the ascorbic acid concentrations. The combined effect of salinity and salicylic acid on ascorbic acid concentration was only prominent at $1 \mathrm{mM}$ $\mathrm{SA}+\mathrm{NaCl}$. 


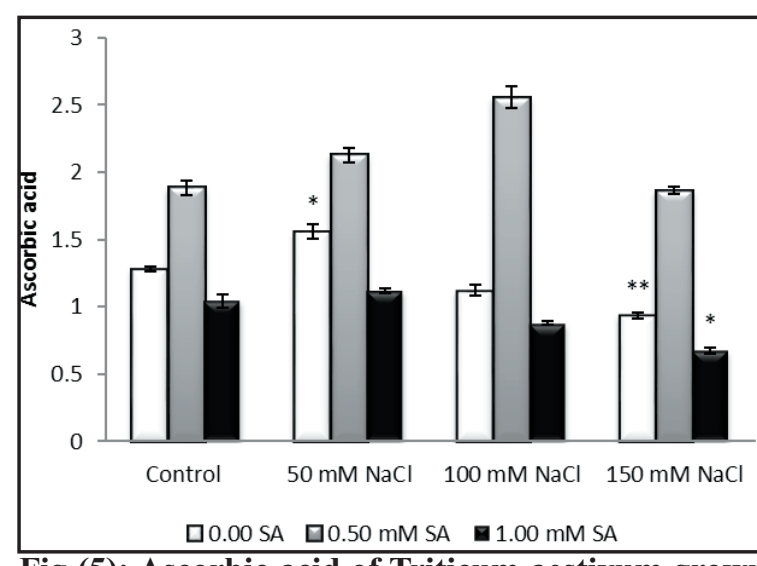

Fig (5): Ascorbic acid of Triticum aestivum grown under different salinity levels and Salicylic acid application (0.00 SA, $0.5 \mathrm{mM} \mathrm{SA}$ and $1 \mathrm{mM} S A)$ for 30 days. The results represent means $\pm \mathrm{SE}$ of at least three independent values. Significant differences $(P \leq 5 \%)$ between values are indicated by stars $(*, * *)$.

Ascorbic acid acts as a primary substrate for neutralization and detoxification of ROS (superoxide radicals and singlet oxygen) in the cyclic pathway because it is a small water soluble antioxidant molecule [52]. In our results, significant decrease of ascorbic acid was observed in combined $\mathrm{NaCl}$ and $\mathrm{SA}$ application; individually applied SA level did not affect much at lower level however salinity has rapid and significant affects. A destructive effect of $\mathrm{Na}$ on enzyme activates reduce the ascorbic acid production and photosynthesis is directly affected by its deficiency as it works as coenzymes in photosynthetic activities [53].

\section{Phenolic compounds:}

The phenolic compounds in wheat leaves were not changed by application of $0.5 \mathrm{mM} \mathrm{SA}$ (as compared to control), while significantly increased by $1 \mathrm{mM} \mathrm{SA}$ (Table 2). On the other hand, salt stress (100 mM and $150 \mathrm{mM} \mathrm{NaCl})$ either alone or in combination with SA levels significantly increased the total phenolic compounds in wheat leaves. The maximum reduction in total phenolic compounds was observed where plants were supplied with $150 \mathrm{mMNaCl}+$ 1 mM SA (Table 2).

Biotic and abiotic stresses especially salinity stimulate synthesis and accumulation of polyphenol in their response [54] Their synthesis participate in plant defense system against production of ROS and environmental stresses impaired photosynthetic and aerobic respiration system [55]. Drastic increase in total phenolic was due to wheat genotypes (cv. Sods 12) have mechanisms to improve phenolics to defend their system against salinity. Salicylic acid have little effect on total phenolic only at higher SA levels, otherwise the effect was not significant (Table 2).

Table (2): Free phenolic, bound phenolic and total phenolic compounds of Triticum aestivum grown under different salinity levels and Salicylic acid application (0.00 SA, 0.5 mM SA and 1mM SA) for 30 days. The results represent means $\pm \mathrm{SE}$ of at least three independent values.

\begin{tabular}{|c|c|c|c|c|}
\hline \multicolumn{2}{|c|}{ Treatments } & Free phenolic & Bound phenolic & $\begin{array}{c}\text { Total phenolic } \\
\text { compounds }\end{array}$ \\
\hline \multirow{4}{*}{$\mathrm{NaCl}$} & Control & $0.01 \pm 1.28$ & $0.008 \pm 0.17$ & $0.022 \pm 1.44$ \\
\hline & $\mathrm{mM} 50$ & $0.10 \pm 1.31$ & $0.005 \pm 0.14$ & $0.014 \pm 1.45$ \\
\hline & $\mathrm{mM} 100$ & $0.02 \pm 1.93$ & $0.006 \pm 0.23$ & $0.016 \pm 2.16$ \\
\hline & $\mathrm{mM} 150$ & $0.02 \pm 2.82$ & $0.010 \pm 0.26$ & $0.017 \pm 3.08$ \\
\hline \multirow{4}{*}{ mM SA 0.5} & Control & $0.02 \pm 2.37$ & $0.005 \pm 0.20$ & $0.024 \pm 2.58$ \\
\hline & $\mathrm{mM} \mathrm{NaCl} 50$ & $0.03 \pm 1.85$ & $0.005 \pm 0.17$ & $0.031 \pm 2.01$ \\
\hline & $\mathrm{mM} \mathrm{NaCl} 100$ & $0.02 \pm 2.10$ & $0.008 \pm 0.23$ & $0.022 \pm 2.34$ \\
\hline & $\mathrm{mM} \mathrm{NaCl} 150$ & $0.02 \pm 1.80$ & $0.008 \pm 0.36$ & $0.017 \pm 2.16$ \\
\hline \multirow{4}{*}{ mM SA 1} & Control & $0.02 \pm 1.43$ & $0.003 \pm 0.16$ & $0.023 \pm 1.59$ \\
\hline & $\mathrm{mM} \mathrm{NaCl} 50$ & $0.05 \pm 3.60$ & $0.002 \pm 0.23$ & $0.042 \pm 3.83$ \\
\hline & $\mathrm{mM} \mathrm{NaCl} 100$ & $0.07 \pm 4.47$ & $0.018 \pm 0.65$ & $0.085 \pm 5.12$ \\
\hline & $\mathrm{mM} \mathrm{NaCl} 150$ & $0.10 \pm 4.65$ & $0.025 \pm 0.81$ & $0.075 \pm 5.46$ \\
\hline
\end{tabular}




\section{Conclusion:}

The present study revealed that salicylic acid treatment (plant-treated with $0.5 \mathrm{mM}$ and $1 \mathrm{mM}$ SA) induced augment of enzymatic antioxidant system (CAT and APX) and non-enzymatic antioxidant system (phenolic and ascorbic acid), reducing oxidative damage (membrane integrity and MDA) in $\mathrm{NaCl}$ stressful conditions. Meanwhile, in control plants submitted to $\mathrm{NaCl}$ stressful conditions the defense mechanisms were not enough to counteract the oxidative damage. The increase in the degree of salt tolerance induced by salicylic acid was also reflected in the improvement in the photosynthetic pigments content and consequently the growth rate in the presence of salinity. Thus, our data provide evidence for the stimulatory effects of salicylic acid to induce salt tolerance in wheat plants.

\section{REFERENCE:}

1. Ashraf M. and Foolad M. R. (2007): Improving plant abiotic-stress resistance by exogenous application of osmoprotectants glycinebetaine and proline. Env. Exp. Bot., 59: 206-216.

2. Ghassemi F., Jakeman A. J. and Nix H. A. (1995): Salinisation of Land and Water Resources: Human causes, extent, management and case studies. University of New South Wales Press, Sydney. 526 pp.

3. Alamgir A. N. M., Musa M. and Ali M.Y. (2008): Some aspects of mechanisms of $\mathrm{NaCl}$ stress tolerance in the seedlings of four rice genotypes. Bangladesh J Bot 36: 181-184.

4. Türkan I. and Demiral T. (2009): Recent developments in understanding salinity tolerance, Enviro. and Exp. Bot., 67: 2-9.

5. Munns R. and Tester M. (2008): Mechanisms of salinity tolerance. Annu Rev Plant Biol.59: 651-81.

6. Munns R. (2005): Genes and salt tolerance: bringing them together, New Phytologist 167: 645-663.

7. El-Tayeb M. A. (2005): Response of barley grains to the interactive effect of salinity and salicylic acid. Plant Growth Regulation. 45: 215-225.

8. Hayat S., Hayat Q., Alyemeni M. N., Wani A. S., Pichtel J. and Ahmad A. (2012): Role of proline under changing environments: a review. Plant Signal. Behav. 7: 1456-1466.

9. Moharekar S. T., Lokhande S. D., Hara T., Tanaka R., Tanaka A. and Chavan P. D. (2003): Effect of salicylic acid on chlorophyll and carotenoid contents of wheat and moong seedlings. Photosynthetica. 41:315-317.

10. Heidari M. and Golpayegani A. (2012): Effects of water stress and inoculation with plant growth promoting rhizobacteria (PGPR) on antioxidant status and photosynthetic pigments in basil (Ocimum basilicum L.), J. of the Saudi Society of Agri. Sci., Vol., 11, Issue 1: $57-61$.

11. Zhang J. and Kirkham M. B. (1994): Drought-stressinduced changed in activities of superoxide dismutase, catalase, and peroxidase in wheat species. Plant Cell Physiology, 35, 785-791.

12. Adly A. A. M. (2010): Oxidative stress and disease: an updated review. Res J Immunol 3: 129-145.

13. Prakash D., Upadyay G. and Pushpangadan P. (2011): Antioxidant potential of some under utilized fruits. Indo-Global J Pharm Sci. 1 (1): 25-32.

14. Sabra A., Daayf F. and Renault S. (2012): Differential physiological and biochemical responses of three Echinacea species to salinity stress. Scientia Hort 135 (24): 23-31.

15. Eyidogan F. and Öz M. T. (2007): Effect of salinity on antioxidant responses of chickpea seedlings. Acta Physiol Plant. 29:485-493.

16. Yusuf M., Hasan S. A., Ali B., Hayat S., Fariduddin Q. and Ahmad A. (2008): Effect of salicylic acid on salinity induced changes in Brassica juncea. J Integrative Plant Biol. 50(8):1-4.

17. Lichtenthaler H. K. (1987): Chlorophylls and caroteniods pigments of photosynthetic biomembranes in Methods in Enzymology vol. 148, 183-350. Academic Press Orlando F.I., USA.

18. Premachandra G. S., Saneoha H. and Ogata S. (1990): Cell membrane stability, an indicator of drought tolerance as affected by applied nitrogen in soybean. J Agr Sci Camb.115: 63-66.

19. Bates L. S., Waldren R. P. and Teare I. D. (1973): Rapid determination of free proline for water stress studies. Plant Soil 39: 205-207.

20. Madhava Rao K.V. and Sresty T.V.S. (1989): Antoxidative parameters in the seedlings of pigeonpea in response to $\mathrm{Zn}$ and Ni stresses. Plant Sci., 2000, 157: 113-128.

21. Kofalvi S. A. and Nassuth A. (1995): Influence of wheat streak mosaic virus infection on phenylpropanoid metabolism and the accumulation of phenolics and lignin in wheat. Physiol. Mol. Plant Pathol. 47(6): 365-377.

22. Jagota S. K. and Dani H.M. (1982): A new colorimetric technique for the estimation of vitamin $\mathrm{C}$ using Folin phenol reagent. Anal. Biochem. 127(1): 178-182.

23. Nakano Y. and Asada K. (1981): Hydrogen peroxide is scavenged by Ascorbate-specific peroxidases in spinach chloroplasts. Plant Cell Physiol., 22: 867-880.

24. Urbanek H., Kuzniak-Gebarowska E. and Herka K. (1991): Elicitation of defense responses in bean leaves by Botrytis cinerea polygalacturonase. Acta Phys. Plant, 13: 43-50. 
25. Pitann B., Mohamed A., Neubert A. and Schubert S. (2013): Tonoplast $\mathrm{Na}+\mathrm{H}+$ antiporters of newly developed maize (Zea mays) hybrids contribute to salt resistance during the second phase of salt stress. J. Plant Nutr. Soil Sci., 176 (2): 148-156.

26. Tavakkoli E., Fatehi F., Conentry S., Rengasamy P. and McDonald G.K. (2011): Additive effects of $\mathrm{Na}$ and $\mathrm{Cl}$ ions on barley growth under salinity stress. J. Exp. Bot., 62: 2189-2203.

27. Orsini F., Alnayef M., Bona A., Maggio A. and Gianquinto G. (2012): low stomatal density and reduced transpiration facilitate strawberry adaptation to salinity. Environ. And Experim. Bot., 81: 1-10.

28. Zhang H. X. and Blumwald E. (2001): Transgenic salttolerant tomato plants accumulate salt in foliage but not in fruit. Nat. Biotechn. 19, 765-768.

29. Mohamed A.S.H and Shaddad M.A.K. (2013): Effect of salinity on dry matter production, ion accumulation, some metabolites and antioxidant enzymes in wheat and broad bean. Al Azhar Bull. Sci. Vol. 24, No. 2: 149164.

30. Misra N. and Misra R. (2012): Salicylic Acid Changes Plant Growth Parameters and Proline Metabolism in Rauwolfia serpentina Leaves Grown under Salinity Stress, American-Eurasian J. Agric. \& Environ. Sci., 12 (12): 1601-1609.

31. Ekmekci Y., Tan Yolac D. and Ayhan B. (2007): Effects of cadmium on antioxidant enzyme and photosynthetic activities in leaves of two maize cultivars. Plant Physiol. 198: 12-14.

32. Sairam R. K., Rao K. V., and Srivastava G. C. (2002): Differential response of wheat genotypes to long term salinity stress in relation to oxidative stress, antioxidant activity and osmolyte concentration. Plant Science 163, 1037-1046.

33. Jaleel C. A., Sankar B., Sridharan R. and Panneerselvam R. (2008): Soil salinity alters growth, chlorophyll contents and secondary metabolite accumulation in Catharanthus roseus. Turkish Journal of Biology. 32: 79-83.

34. Palma F., López-Gómez M., Tejera N. A. and Lluch C. (2013): Salicylic acid improves the salinity tolerance of Medicago sativa in symbiosis with Sinorhizobium meliloti by preventing nitrogen fixation inhibition. Plant Sci., 208: 75-82.

35. Iqbal M. R. K., Iqbal N., Masood A., Per T. S. and Khan N. A. (2013): Salicylic acid alleviates adverse effects of heat stress on photosynthesis through changes in proline production and ethylene formation, Plant Signaling \& Behavior 8:11, e26374.

36. Ben Ahmed C., Ben Rouina B., Sensoy S., Boukhriss S. and Abdullah F (2010): Exogenous proline effects on photosynthetic performance and antioxidant defense system of young olive tree. J Agricult Food Chem. 58: 416-422.
37. Mishra A. and Choudhuri M. A. (1999): Effects of salicylic acid on heavy metal induced membrane degradation mediated by lipoxygenase in rice [J]. Biol Plant, 42: 409-415.

38. Mittler R. (2002): Oxidative stress, antioxidants and stress tolerance. Trends Plant Sci 7: 405-410.

39. Dionisiases M. L. and Tobita S. (1998): Antioxidant responses of rice seedlings to salinity stress. Plant Sci. 135: 1-9.

40. Sudhakar C., Lakshmi A. and Giridarakumar S. (2001): Changes in the antioxidant enzyme efficacy in two high yielding genotypes of mulberry (Morus alba L.) under $\mathrm{NaCl}$ salinity. Plant Sci. 161: 613- 619.

41. Alscher R. G., Erturk N. and Heath L. S. (2002): Role of superoxide dismutases (SODs) in controlling oxidative stress in plants. J Exp Bot 53: 1331-1341.

42. Hassanein R. A., Hassanein A. A., Haider A. S. and Hashem H. A. (2009): Improving salt tolerance of Zea mays L. plant by presoaking their grains in glycine betaine. Aust J Basic Appl Sci. 3: 928-942.

43. Farouk S. (2011): Osmotic adjustment in wheat flag leaf in relation to flag leaf area and grain yield per plant, J. stress Physio. \& Bioch., Vol. 7 No. 2: 117-138.

44. Ahmad P, Umar S (2011): Oxidative stress: role of antioxidants in plants. Studium Press, New Delhi. 19-53.

45. Hu L., Li H., Pang H. and Fu J. (2012): Responses of antioxidant gene, protein and enzymes to salinity stress in two genotypes of perennial ryegrass (Lolium perenne) differing in salt tolerance. J plant physiol. 169 (2): 146-156.

46. Masood S., Saleh L., Witzel K., Plieth C., and Mühling K.H. (2012): Determination of oxidative stress in wheat leaves as in $\mathrm{fl}$ uenced by boron toxicity and $\mathrm{NaCl}$ stress. Plant Physiol. Biochem. 56: 56-61.

47. Amor N. B., Jiménez A., Megdiche W., Lundqvist M., Sevilla F. and Abdelly C. (2006): Response of antioxidant systems to $\mathrm{NaCl}$ stress in the halophyte Cakile maritime. Physiol Plantarum 126: 446-457.

48. Mhadhbi H., Fotopoulos V., Mylona P. V., Jebara M., Aouani M. E. and Polidoros A. N. (2011): Antioxidant gene-enzyme responses in Medicago truncatula genotypes with different degree of sensitivity to salinity. Physiol Plant. 141: 201-214.

49. Feierabend J., Schaan C. and Hertwing B. (1992): Photoinactivation of catalase occurs under both high and low temperature stress conditions and accompanies photo inhibition of photosystem II. Plant Physiol. 110: 1554-1561.

50. Lee H., Guo Y., Ohta M., Xiong L. M., Stevenson B. and Zhu J. K. (2002): LOS 2, a genetic locus required for cold-responsive gene transcription encodes a bifunctional enolase. EMBO Journal 21, 2692-2702.

51. Gengmao Z., Quanmei S., Yu H., Shihui L. and Chang- 
hai W. (2014): The Physiological and Biochemical Responses of a Medicinal Plant (Salvia miltiorrhiza L.) to Stress Caused by Various Concentrations of NaCl. PLoS ONE 9(2): e89624. doi:10.1371/journal.pone.0089624.

52. Noctor G. and Foyer C. H. (1998): Ascorbate and glutathione: Keeping Active Oxygen Under Control. Annu. Rev. Plant Physiol. Plant Mol. Biol. 49: 249-279.

53. Smirnoff N. (2000): Ascorbic acid: metabolism and functions of a multi-facetted molecule. Curr. Opin. Plant Biol. 3(3): 229-35.
54. Ksouri R., Megdiche W., Debez A., Falleh H. Grignon C. and Abdelly C. (2012): Salinity effects on polyphenol content and antioxidant activities in leaves of the halophyte Cakile maritima. Plant Physiol. Biochem. 45(3-4): 244-9

55. Bettaieb I., Hamrouni-Sellami I., Bourgou S., Limam F. and Marzouk B. (2010): Drought effects on polyphenol composition and antioxidant activities in aerial parts of Salvia officinalis L. Acta Physiol. Plant. 33(4): 1103-1111. 